\title{
Re-Conceptualization of Scientific Literacy in South Korea for the 21st Century
}

\author{
Kyunghee Choi, ${ }^{1}$ Hyunju Lee, ${ }^{1}$ Namsoo Shin, ${ }^{2}$ Sung-Won Kim, ${ }^{1}$ \\ Joseph Krajcik ${ }^{2}$ \\ ${ }^{1}$ WCU Global Institute for STS Education, Ewha Womans University, Seoul, South Korea \\ ${ }^{2}$ University of Michigan, Ann Arbor, Michigan
}

Received 29 September 2010; Accepted 23 May 2011

\begin{abstract}
As the context of human life expands from personal to global, a new vision of scientific literacy is needed. Based on a synthesis of the literature and the findings of an online survey of South Korean and US secondary science teachers, we developed a framework for scientific literacy for South Korea that includes five dimensions: content knowledge, habits of mind, character and values, science as a human endeavor, and metacognition, and self-direction. The framework was validated by international science educators. Although the names of these dimensions sound familiar, the framework puts a new perspective on scientific literacy by expanding and refining each dimension, stressing integrated understanding of big idea and the importance of character and values, adding metacognition, and emphasizing global citizenship. Twenty-first century citizens need integrated understanding of the big ideas of science and habits of mind such as systematic thinking and communications. They also need to realize that science is a human endeavor that changes, as new evidence is uncovered. However, these aspects of scientific literacy provide only a partial picture. Scientific literacy should also emphasize character and values that can lead learners to make appropriate choices and decisions to ensure a sustainable planet and provide all people with basic human rights. Individuals will also need to develop metacognitive skills in order interpret new complex scientific information and know when they need additional information. Although this framework was developed primarily for South Korea, a new vision of scientific literacy that is applicable for K-12 has the potential to spur the development of new standards, curriculum materials, instructional practices, professional development and assessments, and dialog across nations. (C) 2011 Wiley Periodicals, Inc. J Res Sci Teach 48: 670-697, 2011
\end{abstract}

Keywords: scientific literacy; global citizenship; globalization; global scientific literacy

\section{Introduction}

The remarkable and rapid advances of science, technology, and engineering have brought about unprecedented changes in the quality of human life. These breakthroughs have united the world in unique ways and have correlated with economic, societal, and political development (Friedman, 2007). New developments in genetics, nanoscience, and neurosciences offer unimaginable opportunities for improving human health. These and other scientific, technology, and engineering developments also give rise to a myriad of ethical, moral, and global

\footnotetext{
Contract grant sponsor: WCU Program, National Research Foundation of Korea; Contract grant number: R3220109.

Correspondence to: H. Lee; E-mail: hlee25@ewha.ac.kr

DOI 10.1002/tea.20424

Published online 21 June 2011 in Wiley Online Library (wileyonlinelibrary.com).
} 
issues that threaten human dignity and survival. The consequences include global warming, lack of energy resources, pandemics, uneven distribution of health and dietary care and supplies, and pollution of our waterways and air (Gore, 2006; Hurd, 1998; Jenkins, 1999). These concerns stretch from the personal to societal and global. They will only be solved through collaboration, communication, and cooperation between people who see themselves as members of a global community. As global citizens, therefore, we need to answer questions such as: What are the likely effects that inventing, manufacturing, and using new nanoscience products will have on the health of my family and the community? What worldwide consequences, if any, could they have? How might we create a sustainable planet in which we meet the energy needs of today without compromising the ability of future generations to meet their own needs? What might be the long-range effects of nanoscale waste on the environment, both locally and globally? How can our world reduce toxic pollutants? To respond to these questions, we need to prepare citizens who have an understanding of scientific ideas, intellectual capabilities, creativity, and reasoning, and to nurture citizens with an awareness and respect of the issues and problems that exist throughout the world so that they can make important environment, health, and social policy decisions for themselves and the global community.

Calls for scientific literacy have existed since the early 1950s. Prominent scientists, such as Conant, Heisenberg, and Oppenheimer, released from their work on the Manhattan Project, immediately called for the education of the scientifically literate citizen in a democratic society-individuals who could understand and contribute to policies surrounding atomic and nuclear escalation (Conant, 1951; Heisenberg, 1958; Oppenheimer, 1954). Since the 1980s, there have been efforts to define and shape what is meant by scientific literacy (AAAS, 1989; Arons, 1983; Bybee, 1997; Gilbert, 2003; Laugksch, 2000; Miller, 1998; Millar \& Osborne, 1998; National Research Council [NRC], 1996; National Science Board, 1996, 1998; Shamos, 1995). These views of scientific literacy provide guidance on what understandings and intellectual capabilities citizens need in order to make informed decisions about issues and problems that occur daily. However, Miller (1998) and Laugksch (2000) argue that because scientific literacy is a socially constructed, it changes with the context and era in which it is used. We agree with this position and will argue that the current views of scientific literacy have limitations with respect to global perspectives and competencies that citizens need for the 21 st century.

The premise of this article is that to meet the demands of the 21 st century global society, it is necessary to rethink current views of scientific literacy and to propose an expanded vision that includes more global perspectives and competencies. We propose a framework for scientific literacy that is needed to educate learners to have the intellectual resources and value orientation necessary to live in a global society. The framework builds on current ideas of scientific literacy and focuses on what all South Korean citizens for the 21 st century need to know and do in response to the increasing rate of scientific and technological advancements and their appended social consequences. Although we propose this framework primarily for South Korea, science educators, and researchers from other countries can use this framework to reflect upon what understandings and competencies their citizens need for the 21 st century. This framework for scientific literacy can guide the development of new curriculum frameworks, instructional materials, instruction, assessment, professional development, and alignment among these elements. To develop this framework, therefore, we asked the following questions: What are the primary characteristics of 21 st century scientific literacy? What key attributes will students need to live productive and fruitful lives in the 21 st century? 


\section{Current Views of Scientific Literacy}

Different organizations have conceptualized the notion of scientific literacy over the past decades (see the extensive reviews of Laugksch, 2000 and DeBoer, 2000 for a more thorough discussion). The Organization for Economic Co-operation and Development (OECD, 2004) describes scientific literacy as "the capacity to use scientific knowledge, to identify questions and to draw evidence-based conclusions in order to understand and help make decisions about the natural world and the changes made to it through human activity" (p. 40). Project 2061 in their seminal volume, Science for all Americans (AAAS, 1989, p. XIII), describes scientific literacy as "the understandings and habits of mind they need to become compassionate human beings able to think for themselves and to face life head on. It should equip them also to participate thoughtfully with fellow citizens in building and protecting a society that is open, decent, and vital." The NRC's National Science Education Standards (NSES) (NRC, 1996) and England's Beyond 2000: Science Education for the Future (Millar \& Osborne, 1998) also advocate that all citizens need a basic level of scientific literacy to make informed choices and decisions about issues and problems that occur daily. NSES describes scientific literacy as "the knowledge and understanding of scientific concepts and processes required for personal decision making, participation in civic and cultural affairs, and economic productivity" (NRC, 1996, p. IX). Millar and Osborne (1998) in Beyond 2000 state that scientific literacy is necessary for all learners growing up in our society regardless of their career aspirations or capabilities. As such, they view a scientific literate individual as "comfortable, competent, and confident with scientific and technical matters and artifacts" and the aim of school science is to produce a populace with such capabilities. These four major documents contain critical ideas about scientific literacy and have shaped science education globally; however, they stress ideas necessary for personal and societal issues and problems and not the understanding and competencies needed for a global society. Because the world-wide-web and other mass media allows citizens in a democracy to have access to global information at anytime and anywhere, and because we have learned more about how students learn since these documents have been published (e.g., Bransford, Brown, \& Cocking, 1999; Duschl, Schweingruber, \& Shouse, 2007), we need to rethink and enhance the ideas put forth in these documents.

Many scholars in science education also identify key elements of scientific literacy. Miller (1998) describes scientific literacy as comprising three areas: (1) a vocabulary of basic scientific concepts sufficient to read competing views in media reports, (2) an understanding of the nature of scientific inquiry, and (3) an understanding of the impact of science and technology on individuals and society. Millar (2006) hypothesizes that science curricula for the 21 st century will stress two key aspects of scientific literacy: (1) scientific ideas needed for an individual to make responsible decisions as member of a democratic society and (2) scientific ideas that are fundamental to the culture of the society. Millar also stresses the importance of building and using contexts that will allow students to use science understandings to make informed choices. Norris and Phillips (2003) present a summary of scientific literacy that includes (1) basic understanding of science ideas and the nature of science, (2) habits of mind, (3) knowledge needed for intelligent participation in science-based social issues, (4) appreciation of, and comfort with, science including a sense of wonder and curiosity, (5) knowledge of the risks and benefits of science; and (6) an ability to think critically about scientific claims and findings. Tyler, in his review of the 2006 Australian Council for Educational Research Conference, calls for a revamping of the science curriculum in Australia to de-emphasize a stress on conceptual knowledge and to focus more on the nature 
and processes of science and the ability to use ideas to explain important aspects of the world in which children live. Like Millar, Tyler argues for rich contexts that provide opportunities for students to use ideas and that will motivate and engage. These views of scientific literacy stress what all citizens, not just those entering scientific fields, need to know to live as productive citizens in a society. Bowen and Roth (2007) and Roth and Lee (2004) provide a more radical view of scientific literacy in which 'community participation' of individuals and 'collective praxis' play important roles in making decisions on the issues within the local context and as such provide the focus for what students will learn. They note that not everybody needs to have the same basic sets of concepts and skills; rather, it is more important to allow "the emergence of scientific literacy as a collective property" (Roth \& Lee, 2004, p. 263).

These views of scientific literacy provide a vision of the knowledge and intellectual capabilities citizens need in order to make informed choices and decisions about issues and problems that occur daily and that affect society; however, with the exception of the Tyler report (Tyler, 2007), these views do not take into consideration a global perspective and the scientific understandings and capabilities that citizens need to live in the 21 st century to build and maintain a sustainable planet for all people. The context of scientific literacy most often lies within a personal and societal framework and does not consider issues related to a global society.

\section{Need for a New Framework for Scientific Literacy in South Korea}

\section{Globalization and School Science Reforms}

Over the past decade, different societal sectors of South Korea have used terms such as "globalization," "global citizens," or "global competitiveness" as catch phrases. A primary driving force for the globalization movement in South Korea is the rapid industrial, technological, and economical development of the country. South Korea has matured into a leading nation for the design and development of new technology, telecommunication, medical science and other industries that make use of scientific advances. In order to meet global standards, South Korea is focusing on cultivating global human resources that will allow individuals not only to understand the content but also the political, social, and cultural underpinnings of trade and international relationships. For instance, many universities in South Korea offer various opportunities for college students to experience education from more developed nations through various exchange programs and encourage faculty to collaborate with international scholars. Even at the secondary school level, numerous students go abroad to obtain a better and more eclectic education experience $(.026 \%$ in $1995 ; .26 \%$ in 2005 ). Another driving force impacting South Korea is the sudden influx of multiculturalism into the society. South Korea has long been regarded as a racially homogenous nation; however, currently it has experienced a continuous increase in international marriage (1.2\% in 1990; $11.1 \%$ in 2007) and registered foreigners (20,525 in 1990; 237,517 in 2005) (From Korean Statistical Information Service, http://www.kosis.kr). It is also now common to see foreign students in local secondary schools. Many individuals pay attention to their cultural backgrounds and feel an urgent need to find avenues for embracing them into our society. Another force, the dual positive and negative impacts of science and technology, affects the Korean societal atmosphere. Almost every day, new technology and scientific research findings beneficial to society are announced through the mass media. At the same time, ethical, moral, and social issues threatening the welfare of life in different places of the world with this growth in science and technology emerge. This force leads the South Korean people to feel 
responsibility as global citizens. The recent accident of the Fukushima Nuclear power plant in Japan caused by earthquakes and the tsunami is one good example. South Korea, as a global companion, dispatched rescuers and volunteers to help the injured and provided economic aids to restore the loss, as did other nations throughout the globe. Individuals from different places of the world felt empathy with the Japanese and their loss. As we tried to argue in the beginning, we are now in a new age when people need to think of issues and problems not only from a personal and society perspective, but from a global perspective in which problems and their solutions affect societies and individuals worldwide. Such a global perspective is critical for developing a sustainable planet in which all people have the basic necessities of life.

The globalization movement has also influenced school curriculum reforms in South Korea. The current national curriculum guide, the 7th Korean National Curriculum for secondary schools (Ministry of Education and Human Resources Development [MEHRD], 2007; Ministry of Education, Science and Technology [MEST], 2009), portrays secondary graduates with autonomous and creative talent who can provide leadership in the 21 st century globalized society. Especially at the high school level (10th-12th), we aim to cultivate student capability and character as future global citizens by fostering creativity and appreciating diverse cultures and values. However, unlike the overall direction of curriculum reforms in South Korea, the National Science Curriculum does not explicitly represent the idea of globalization and global citizens. The Social Studies Curriculum includes some ideas related to globalization such as multiculturalism and global citizenship.

What we have tried to argue in the above paragraphs is that although globalization is accepted and seen as important by South Koreans, globalization is still an abstract and not actualized idea in the science curriculum (Kang, Park, \& Baek, 2008). The concept of scientific literacy presented in the National Science Curriculum is consistent with this position. From 1992 to the present, a primary goal of science education was to educate students to become scientifically literate citizens. However, major elements of scientific literacy suggested in curriculum are still limited to (1) basic scientific knowledge, (2) scientific process and inquiry skills, (3) affective components (e.g., attitudes, interests, curiosity, etc.), and (4) understanding the interrelationship among science, technology, and society (MEHRD, 2007; Ministry of Education, 1992, 1997). The National Science Curriculum 2009, which has been implemented since 2011, started to emphasize "character development as global citizens" for the high school science (MEST, 2009); however, only one elective science course for the 10th grade students covers such global issues as information technology, health technology, and energy and environment under the theme of "science and contemporary culture" in the content standards. Furthermore, the meaning of "character development as global citizens" and strategies to help schools and teachers move in this direction are not still explicitly suggested. Thus, many science teachers are hesitant to address these new topics and do not know what would be a better direction for effective teaching for 10th grade science. South Korean science educators, therefore, remain doubtful of the effectiveness of the current science education curriculum to meet the societal demands, and seek a clearer vision for the 21 st century scientific literacy.

\section{PISA Results}

The results from the Organization for Economic Co-operation and Development (OECD) Program for International Student Assessment (PISA), 2006 (OECD, 2007) further fueled regarding the best direction for South Korea to take in education. The PISA results showed that South Korean students suffered a steady decline in performance in science over in recent 
years. South Korea, the top performer in 2000, slumped to 11th out of 57 countries in 2006 . PISA 2006 Science was designed to measure scientific knowledge (e.g., knowledge of science content, knowledge about science), scientific competency (e.g., identifying scientific issues, explaining phenomena scientifically, using scientific evidence), and attitudes of science (e.g., support for scientific inquiry, self-belief as science learners, interest in science, responsibility towards natural resources and the environments) in real-life contexts. The assessment results showed that Korean students have relatively low understanding of living systems, and low competency in applying scientific knowledge for describing and analyzing phenomena. Moreover, South Korean students' self-efficacy and self-concept in science was also lower than the OECD average with only $27 \%$ reporting that they enjoyed solving science problems, whereas the OECD average was $43 \%$. Although Korean students felt responsible for sustainable development, they held low awareness of environmental issues such as the importance of developing forests for other land use, the impact of acid rain, increase in greenhouse gases emissions and nuclear waste on the environment, and potential health consequences of genetically modified organisms (M. Lee, Sohn, \& No, 2008).

The PISA findings differ from the latest findings of the Trends in International Mathematics and Science Study (TIMSS). On TIMMS, Korean students performed fairly well, taking second place in mathematics and fourth place in science (Martin, Mullis, \& Foy, 2008). However, the PISA assessment focused more on what students know, value and are able to do with the science within reasonable and appropriate personal, social, and global contexts, whereas the TIMMS assessment focused more on the reproduction of facts and solving problems using algorithms. The formats of PISA and TIMMS items also differ. TIMMS items are mainly multiple choice, whereas many PISA items are constructed response or multiple questions from one stem. The differences between the PISA and TIMMS results can be partially explained because South Korea's science education, that rarely goes beyond the exclusive focus of the canonical ideas of science, may fall short of helping students use ideas and problem solve even though it may be effective in helping them comprehend scientific concepts. The overall conditions of South Korea call for the new framework for scientific literacy for a global society that can guide the development of science curriculum, instructional materials, professional development, and alignment among these elements. The framework needs to embrace educational concerns for individuals who are intellectually and morally responsible in the global context.

\section{Procedure of Developing a Conceptual Framework for Scientific Literacy}

In order to develop our conceptual framework for scientific literacy, we went through the following four phases: (1) extensive reviews of literature on scientific literacy, (2) analysis of an on-line survey with science teachers, (3) conceptualization of the 21 st century scientific literacy, and (4) validation of the conceptual framework with expert group.

\section{Phase 1: Extensive Reviews of Literature on Scientific Literacy}

To more precisely characterize scientific literacy for the 21 st century and to synthesize a framework for scientific literacy, we conducted an extensive review of the science education literature and debated various ideas (e.g., Arons, 1983; Bybee, 1997; Chen, Shi, \& Xu, 2009; DeBoer, 2000; Holbrook \& Rannikmae, 2007; Hurd, 1998; Laugksch, 2000; Miller, 1998; Norris \& Phillips, 2003; Pella, O’Hearn, \& Gale, 1966; Roth \& Lee, 2004; Shamos, 1995; Shen, 1975). We also reviewed public documents published by organizations in different countries, such as NSES (NRC, 1996), Benchmarks for Science Literacy (AAAS, 1993), and Beyond 2000 (Millar \& Osborne, 1998). In addition, in order to represent capabilities for 
the 21 st century, we analyzed a 21 st century skills map (P21, 2009). As discussed above, most of the conceptions regarding scientific literacy in the documents and literature could be classified as having four major dimensions: conceptual understanding, habits of mind, affective realm (i.e., motivation and attitudes), and science as a human endeavor.

\section{Phase 2: On-Line Survey With Science Teachers}

Views on scientific literacy presented in the literature mostly tell what policy makers, organization officials, and researchers have considered as important elements of scientific literacy. We wondered what practitioners who actually teach science in schools believed about scientific literacy and how they envision global citizenship for the 21 st century. We also sought to see to what extent the views of practitioners and the ideas in the literature are consistent or contradictory. In order to achieve this aim, we simultaneously investigated science teachers' perspectives through on-line survey as we conducted our literature review. We expected that teachers' views might suggest more practical ideas and visions for global citizens.

The survey consisted of 42 items using a Likert-type format (1: not very important to 5: very important) that asked teachers' perception on the importance of key elements of scientific literacy in terms of four dimensions (i.e., conceptual understanding, habits of mind, motivation and attitudes, and the nature of science). Chronbach Alphas for internal consistencies of the four dimensions ranged from .56 to .90 (total $=.91$ ). The survey also included one openended item asking teachers to write their opinion about "what they anticipate their students to be like as citizens in the 21 st century society?"

We created a web site for the on-line survey and distributed advertisement through a website and list servers of science teacher associations to request teacher participation. The survey was open over a 2-month period. In South Korea, a total of 96 science teachers (49 middle school and 43 high school teachers), including 26 males and 66 females, with average teaching experience of 9.4 years responded voluntarily to the survey. Four teachers did not specify their schools and gender. In the US, a total of 126 teachers (42 middle school and 78 high school teachers) including 43 males and 79 females responded. The average teaching experience of the US teaching was 15.7 years. The nationality of the US teachers included 120 USA citizens, 1 Mexican, 2 Canadians, and 1 Pilipino. Four teachers did not provide their nationality, six teachers did not identify their gender, and eight teachers did not indicate their teaching grade level. In this article, we focused on analyzing teacher responses to the open-ended item. We identified some key elements of scientific literacy for global citizens from the responses and then categorized the elements into four dimensions that emerged in Phase 1. We present statistical results of Likert scale item analysis to support the findings that emerged from the analysis of the open-ended item.

Science Teachers' Views on Scientific Literacy for 21st Century Global Citizens. First, in the category of conceptual understanding, the science teachers emphasized basic scientific knowledge to understand natural phenomena, science terms and vocabulary presented in newspaper or magazines, and science knowledge necessary for students to understand or make a decision on science-related issues. Table 1 shows representative quotes from the teachers. These quotes indicate some consistency with the results of the Likert-type item analysis. Korean science teachers responded the highest to "scientific knowledge in daily life" (e.g., why the sky is blue, why we use chlorine to clean water in swimming pools) $(M=4.31)$ and US science teachers responded the highest to "knowledge regarding sciencerelated social, ethical, or moral issues" $(M=4.63)$. The responses made by the teachers also 
Table 1

Exemplary Quotes Related to Content Knowledge

\begin{tabular}{|c|c|}
\hline Responses & Examples \\
\hline $\begin{array}{l}\text { Basic scientific knowledge } \\
\text { to understand natural phenomena }\end{array}$ & $\begin{array}{l}\text { "I don't want them to accept the first explanation or reasoning } \\
\text { for something, but I want them to delve deeper with their } \\
\text { understanding so that they can form their own understanding } \\
\text { that fits with their prior constructed knowledge." } \\
\text { "My goal is for my students to leave school with a science } \\
\text { background strong enough to understand natural phenomena." }\end{array}$ \\
\hline Science terms in media & $\begin{array}{l}\text { "They are expected to work on vocabulary through articles, } \\
\text { readings, journals they are keeping and research projects. .." } \\
\text { "Citizens should be able to pick up newspaper or magazine articles } \\
\text { and be able to understand the content." }\end{array}$ \\
\hline $\begin{array}{l}\text { Knowledge necessary for } \\
\text { understanding science-related issues }\end{array}$ & $\begin{array}{l}\text { "Students should understand science-related issues, such as } \\
\text { environmental pollutions, health problems..." } \\
\text { "Citizens should have a sufficient scientific background to be able } \\
\text { to understand relevant aspects of global issues-bioengineered } \\
\text { foods, global warming, energy use, petroleum reserves, etc." }\end{array}$ \\
\hline
\end{tabular}

connect with literature (e.g., Millar, 2006; Miller, 1998); however, the teachers seemed to lack understanding of the importance of big ideas and more integrated understanding of science cutting across various traditional disciplinary boundaries (e.g., Bransford et al., 1999; Kesidou \& Roseman, 2002; Linn \& Eylon, 2006; Roseman, 2010).

Second, in the category of habits of mind, the teachers generally put most emphasis on critical thinking, problem solving, and informed decision-making skills for everyday life issues. This finding shows some consistency with the results of the Likert-type item analysis. Korean teachers gave the highest response to "evidence (scientific knowledge)-based critical thinking skills" $(M=4.33)$, and "ability to explain logically by using scientific evidence" $(M=4.28)$. US science teachers responded similarly as Korean teachers, but responded to "evidence (scientific knowledge)-based critical thinking skills" slightly higher $(M=4.74)$. These skills are often regarded as important habits of mind in literature (e.g., Duschl et al., 2007; Norris \& Phillips, 2003). The teachers' open-ended responses also included ideas that that students need to learn how to manage the flood of information (i.e., information management skills such as finding relevant information, organizing, analyzing, and evaluating information) and how to collaborate and communicate with a wide range of people to solve problems. A small number of the teachers mentioned the ability to use appropriate technologies. The teachers' open-ended responses seemed to envision the global context that their students will face in the 21 st century. Table 2 includes representative examples for each of these elements.

Third, the type of responses teachers made in the affective realm included three areas: Interest and positive attitudes toward science, responsibility, and participation in science, and ethics about caring for other people and living creatures. However, unlike conceptual understanding and habits of mind categories, over two-thirds of the participating teachers did not write any statement regarding the affective realm. Of those that did, the major emphasis was placed on developing a long lasting interest and positive attitudes toward science. Similarly, in the Likert-type items, Korean teachers gave the highest response to "interest toward science" $(M=4.23)$. US teachers were also high on this item $(M=4.15$ for US teachers). 
Table 2

Exemplary Quotes Related to Habits of Mind

\begin{tabular}{|c|c|}
\hline Responses & Examples \\
\hline $\begin{array}{l}\text { Critical thinking, } \\
\text { problem solving, } \\
\text { and decision-making skills }\end{array}$ & $\begin{array}{l}\text { "The expectations I have for my students as far as them being citizens in } \\
\text { the } 21 \text { st century, is that they will be skilled in, reasoning, critical } \\
\text { thinking, and problem solving." } \\
\text { "My main goal in educating my students is to give them enough scientific } \\
\text { knowledge that they can use to critically scrutinize claims of scientific } \\
\text { validity for themselves and then determine if the claims are valid or } \\
\text { not..." } \\
\text { "I expect them to be able to make informed decisions, to be able to } \\
\text { research issues on their own, and to be able to weigh pros and cons." }\end{array}$ \\
\hline $\begin{array}{l}\text { Information management } \\
\text { skill }\end{array}$ & $\begin{array}{l}\text { "Students need to be able to think critically and analyze information } \\
\text { presented in the media regarding any scientific concepts, and to be able } \\
\text { to evaluate the information presented to them in the course of daily life." } \\
\text { "Students should be able to evaluate information from a variety of } \\
\text { perspectives." } \\
\text { "I expect my students to be able to critically evaluate the information } \\
\text { bombarding them from media and special interest groups." }\end{array}$ \\
\hline $\begin{array}{l}\text { Communication and } \\
\text { Collaboration }\end{array}$ & $\begin{array}{l}\text { "I believe that } 21 \text { st century students will need communication } \\
\text { skills - societal skills, written and electronically generated } \\
\text { communications..." } \\
\text { "I expect students will have to be able to collaborate in teams to } \\
\text { address new situations, to generate possible outcomes and to make } \\
\text { recommendations based on sound scientific principles." }\end{array}$ \\
\hline Use of technology & $\begin{array}{l}\text { "Our goal is to teach them to utilize various technologies to make } \\
\text { work/life simpler. We want them to be able to function in a society where } \\
\text { technology is very important and growing all the time." } \\
\text { "I would hope that they would be better prepared to use the technology } \\
\text { which keeps developing." }\end{array}$ \\
\hline
\end{tabular}

The focus on students developing positive attitudes may indicate teachers deserve for students to study science further and not to play a role as a driving force as citizens who take responsibility and actions to resolve science related issues for larger purposes. Some teachers, however, do hold this broader vision and wrote statements about students being aware and responsible and active participations in resolving socioscientific issues. Some other teachers mentioned ethics of care (i.e., care for people and living creatures) and empathy as important elements of global citizens. Table 3 shows representative quotes from the teachers.

In the category of science as a human endeavor, teachers' open-ended responses generally put emphasis on understanding limitation of science because scientific knowledge is a product of human activities. They also wrote that students need to understand how science affects individuals and society; however, interestingly they did not mention the reverse (i.e., how society affects scientific development). In addition, a small number of the teachers mentioned the spirit of science that includes skepticism and values of science (e.g., to discover and explain certain phenomena, to develop technology for larger well being, etc.). The results of the Likert-type and the selection items have some consistency with the open-ended responses. Korean teachers responded that understandings of "the tentativeness of science" 
Table 3

Exemplary Quotes Related to Affective Realm

\begin{tabular}{|c|c|}
\hline Responses & Examples \\
\hline $\begin{array}{l}\text { Interest and positive } \\
\text { attitudes toward } \\
\text { science }\end{array}$ & $\begin{array}{l}\text { "I want them to develop a continuing interest in learning and science." } \\
\text { "I hope to inspire them to love science as much as I do." } \\
\text { "I hope my students will be able to pick up a newspaper or magazine." }\end{array}$ \\
\hline $\begin{array}{l}\text { Responsibility } \\
\text { and participation }\end{array}$ & $\begin{array}{l}\text { "I hope that my students will become productive citizens of the world with an } \\
\text { understanding that we are all responsible for protecting the world we live in." } \\
\text { "I want my students to be active stewards for the environment in their communities." } \\
\text { "As democratic citizens they should feel a duty to monitor and support sound science } \\
\text { as it applies to the environment, new technology in all phases, and support sound } \\
\text { programs of research. They would do this by continuing to advance their } \\
\text { knowledge base through continued reading (books, newspaper articles, magazines } \\
\text { and various science programs available on the electronic media)." }\end{array}$ \\
\hline Ethics of care & $\begin{array}{l}\text { "They should take care of others, their communities, not just take care of } \\
\text { themselves." } \\
\text { "I want them to understand how scientific development can negatively affect other } \\
\text { people and be sympathetic to them." } \\
\text { "I anticipate students at every grade level have been learning to be citizens which are } \\
\text { accepting of others' cultures and welcome globalization. Scientifically, this } \\
\text { awareness comes with an understanding and respect for global ecology concerns." }\end{array}$ \\
\hline
\end{tabular}

( $M=4.19)$, "ethical aspects of science" $(M=4.18)$, and "interrelationship of STS" $(M=4.16)$ are important elements. However, US teachers responded the highest to "ability to distinguish science from pseudo-science" $(M=4.57)$. Table 4 includes representative examples for each of these elements.

In general, the survey results show that science teachers understanding of scientific literacy for global citizens are somewhat consistent with the literature. From the teacher responses, we found support for the importance of some elements such as communication and

Table 4

Exemplary Quotes Related to Nature of Science

\begin{tabular}{l} 
Responses \\
\hline Limitation of science "I hope that my students understand that scientists cannot know everything, ... the \\
difference between science and non-/pseudo- science" \\
"Students must understand the nature of science...... They must understand what \\
science can and cannot do" \\
"They should know in what ways science contributes to the development of our \\
society, how science plays important role in the society..." \\
"This would require an interest in how science affects them as individuals, in societal \\
groups within individual countries as well as in a global world." \\
"I expect students to understand the importance of various scientific discoveries and \\
technological advances in order to promote a sustainable society ..." \\
"I expect from my students to have healthy skepticism..."
\end{tabular}


Table 5

Other Elements With Exemplary Quotes

\begin{tabular}{l} 
Responses \\
\hline Life-long learning \\
$\begin{array}{l}\text { "I expect my students to be life-long learners not only in science but in other fields." } \\
\text { "They must learn how to learn on their own and must love learning for learning's } \\
\text { sake." }\end{array}$ \\
"I want them to ask, 'Does this make sense? Is this in line with what I already know \\
"I be truth?" \\
$\begin{array}{l}\text { "I expect that my students to be lifelong learners. I hope that I inspire them to } \\
\text { continue to learn, ask questions, and above all, do not take everything for granted } \\
\text { in the physical universe." }\end{array}$
\end{tabular}

collaboration, and information management in the habits of mind dimension, and ethic of care and empathy in the affective realm. A new dimension, however, emerged from the teachers' open-ended responses. Some teachers portrayed the importance of self-directed learners who are able to enjoy and manage their learning, using such terms as "lifelong learner" and "continue to learn." The responses also indicated a need for metacognitive skills. Table 5 includes representative quotes from the teachers. Although this capability coincided with the one suggested by P21 (2009), most of the current literature on scientific literacy does not embrace metacognition.

\section{Phase 3: Conceptualization of the 21st Century Scientific Literacy Framework}

Based on the literature review, survey results and teachers' open-ended responses, we had consecutive discussions debating the primary characteristics of 21 st century scientific literacy and what key attributes students will need to live productive and fruitful lives in the 21 st century. We reached a consensus on portraying individuals who integrated understanding of the big ideas of science, could appreciate diversity of cultures and values, participate in construction of social values through collaboration and communication with others, responsibly take an action on the science-related global issues, and ultimately develop character and values as a member of a global society.

In order to characterize this vision, first of all, like the PISA framework (OECD, 2007), we accepted the importance of student engagement in a variety of situations; that is, personal context (issues about themselves, family, or acquaintances), societal context (issues of their local communities or countries), and global context (issues of global nature). Through this iterative analysis of examining the literature and reflecting on the teachers responses, we identified five dimensions of the 21st century Scientific Literacy: (1) content knowledge, (2) habits of mind, (3) character and values, (4) science as a human endeavor, and (5) metacognition and self-direction (see Table 6; Fig. 1 in the next section). Three dimensionscontent knowledge, habits of mind, and science as human endeavor-align with previous conceptions of scientific literacy; however, the descriptions and key elements go beyond how scientific literacy is currently envisioned. For instance, in the dimension of content knowledge we emphasized big ideas of science (Duschl et al., 2007; C. L. Smith, Wiser, Anderson, \& Krajcik, 2006; Stevens, Sutherland, \& Krajcik, 2009) which allow individuals to explain and predict a variety of phenomena and issues. The use of big ideas is consistent with the New Science Education Framework being proposed in the US (NRC, 2010). In the habits of mind 
Table 6

Description of Five Dimensions of Scientific Literacy for the 21st Century

\begin{tabular}{|c|c|c|}
\hline Dimensions & Description & Key Elements \\
\hline $\begin{array}{l}\text { Content } \\
\text { knowledge }\end{array}$ & $\begin{array}{l}\text { Integrated, context-based scientific understanding of } \\
\text { core science content that helps think within and } \\
\text { across the disciplines to understand and use this } \\
\text { understanding for socio-scientific issues } \\
\text { Current Scientific literacy: Understanding of basic } \\
\text { ideas and vocabulary }\end{array}$ & $\begin{array}{l}\text { Big ideas that explain a } \\
\text { host of phenomena }\end{array}$ \\
\hline Habits of mind & $\begin{array}{l}\text { Competencies to solve complex personal, community } \\
\text { and global problems collaboratively with others by } \\
\text { critically examining issues, finding and using } \\
\text { resources, applying core ideas, and arguing for and } \\
\text { against positions using sufficient evidence and } \\
\text { reasoning to support claims } \\
\text { Current Scientific Literacy: Inquiry skills }\end{array}$ & $\begin{array}{l}\text { Communication and col- } \\
\text { laboration } \\
\text { Systematic thinking } \\
\text { Use of evidence to support } \\
\text { claims } \\
\text { Information management }\end{array}$ \\
\hline $\begin{array}{l}\text { Character } \\
\text { and values }\end{array}$ & $\begin{array}{l}\text { Belief system and preferences to act responsibly with } \\
\text { respect to human life and compassion for other } \\
\text { human beings throughout the globe. This belief } \\
\text { system serves as a driving force for individuals to } \\
\text { act responsibly as citizens of technologically and } \\
\text { scientifically advanced } 21 \text { st century society } \\
\text { Current Scientific literacy: Attitude, motivation }\end{array}$ & $\begin{array}{l}\text { Ecological worldview } \\
\text { Socio-scientific } \\
\text { accountability } \\
\text { Social and moral } \\
\text { compassion }\end{array}$ \\
\hline $\begin{array}{l}\text { Science as } \\
\text { human } \\
\text { endeavor }\end{array}$ & $\begin{array}{l}\text { Understanding that science knowledge is a human } \\
\text { construct, theory-laden, tentative, based on } \\
\text { evidence, testable and creative } \\
\text { Understanding of collaborative and interdisciplinary } \\
\text { nature of science, and the relationship between } \\
\text { science and society } \\
\text { Current Scientific Literacy: Isolated silos of people } \\
\text { solving critical problems and science as finding out } \\
\text { how the world "truly works" }\end{array}$ & $\begin{array}{l}\text { Characteristics of } \\
\text { scientific knowledge } \\
\text { Science and Society } \\
\text { The spirit of science }\end{array}$ \\
\hline $\begin{array}{l}\text { Metacognition and } \\
\text { self-direction }\end{array}$ & $\begin{array}{l}\text { Explicit understanding one's own cognition and } \\
\text { cognitive ability in order to reflect upon one's level } \\
\text { of knowledge to know if one understands, or if more } \\
\text { information is necessary. Such knowledge allows an } \\
\text { individual as life-long learners to check work, seek } \\
\text { new information to answer questions, decide if } \\
\text { more information is needed, out of their own } \\
\text { initiatives } \\
\text { Current Scientific Literacy: While in the literature, not } \\
\text { a focus for scientific literacy }\end{array}$ & $\begin{array}{l}\text { Self-directed planning } \\
\text { Self-directed monitoring } \\
\text { Self-directed evaluating }\end{array}$ \\
\hline
\end{tabular}

dimension, beyond inquiry skills, we included communication and collaboration skills and information management skills such as finding and using resources and critically evaluating their quality. And in the dimension of science as a human endeavor, we put emphasis on understanding the collaborative and interdisciplinary nature of science. Moreover, we expanded the affective realm into character and values, beyond attitudes and motivation toward 


\section{Scientific Literacy for the $21^{\text {st }}$ Century}

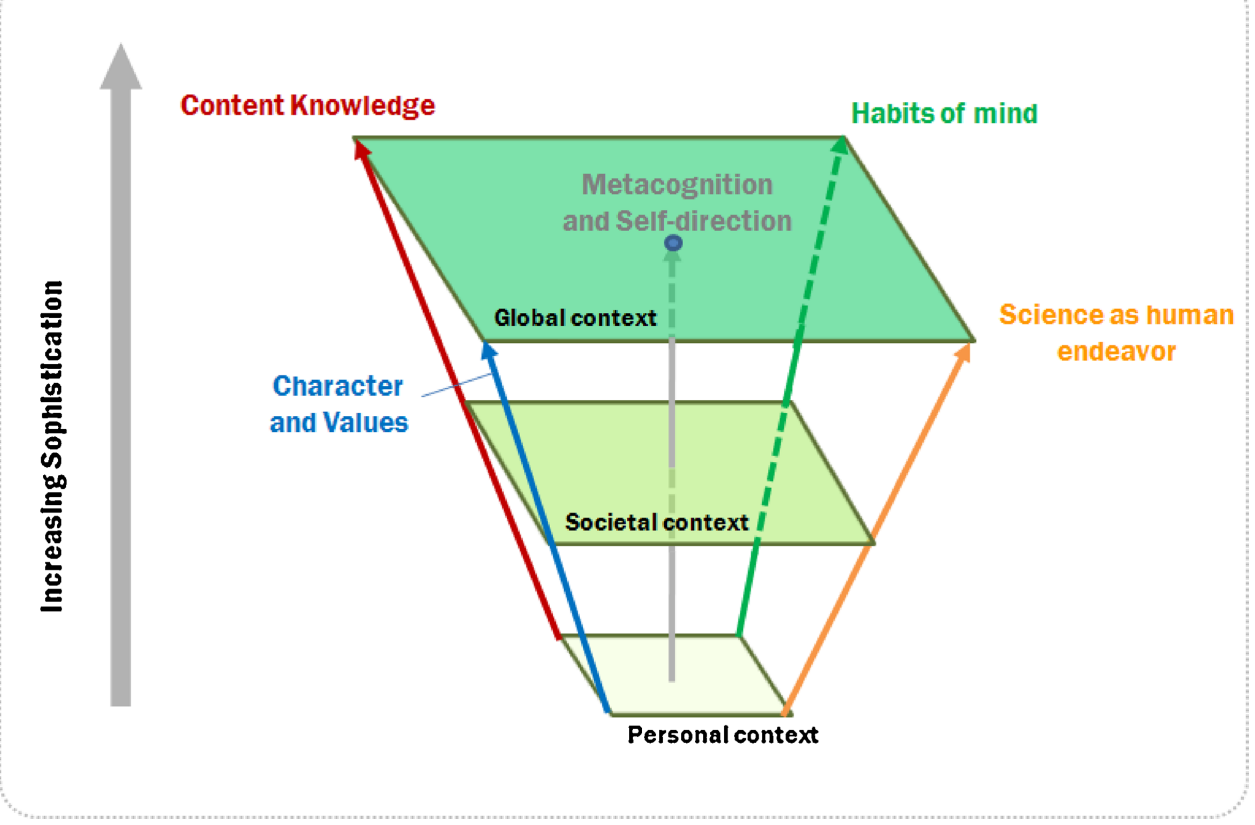

Figure 1. Five dimensions of scientific literacy for the 21st Century.

science. Our portrayals of global citizens are active agents who take responsibility to resolve global issues with moral and social compassion and ecological worldview. Lastly, we included metacognition and self-direction as a major dimension of global scientific literacy. Our consideration for including this dimension to the framework was initiated by examining the opened-ended survey responses because this dimension is saliently missing from other documents on scientific literacy. Yet, we see this dimension as critical for $21 \mathrm{st}$ century scientific literacy as it is the process that ties the other four dimensions together and supports an individual in reflecting and managing cognition and learning, in solving complex problems, and dealing with challenging local and global issues. Some literatures (e.g., Brown, 1987; Leahey \& Harris, 1997; OECD, 2005) also support ideas associated with metacognition. For instance, the OECD's Definition and Selection of Competencies (DeSeCo) Project (2005) also mentioned reflectiveness, which implies the use of metacognitive skills, as "the heart of key competencies" (p. 8), and stated "it (reflectiveness) is not just about how individuals think, but also about how they construct experience more generally, including their thoughts, feelings, and social relations. This requires individuals to reach a level of social maturity that allows them to distance themselves from social pressures, take different perspectives, make independent judgments, and take responsibility for their actions" (p. 9).

After reaching a consensus on the five dimensions, we adapted Construct-Center Design process (CCD) that focuses explicitly on clarifying and specifying content (Shin, Stevens, \& Krajcik, 2011) and carefully unpacked what each dimension and key element meant through an extensive review of ideas from the literature on each of these dimensions. Details of each dimension and key elements will be discussed in the next section. 


\section{Phase 4: Validation of the Conceptual Framework With Expert Group}

To receive feedback and validate our framework, we invited five science educators from the US and Australia to review our documents. With each of the science educators, we reviewed the unpacking of the framework together. And we clarified each element and sentence on the basis of the feedback to finalize the conceptual framework.

\section{A New Framework for the 21st Century Scientific Literacy}

Table 6 provides an overview of the framework for 21st century scientific literacy that includes a brief description and key elements of each dimension, and presents a brief comparison to show how the dimension was previously described and what is new. Figure 1 presents how each dimension is connected with another within the personal, societal, and global context.

\section{Content Knowledge}

Content knowledge refers to the scientific concepts, the overarching principles and the relationships among these ideas needed to describe and explain phenomena that individuals encounter in their lives. Content knowledge is the common denominator in various descriptions of scientific literacy. Benchmarks (AAAS, 1993) present a common core of science ideas that all learners need and are expected to understand to obtain scientific literacy. NSES (NRC, 1996) focus on a basic level of knowledge and understanding of scientific concepts needed to make informed choices and decisions. NSES authors also support "less is more" and state that the coverage of all topics, vocabulary, and information presented in textbooks directly conflicts with students developing scientific knowledge with understanding. PISA (OECD, 2004) describes content as helping individuals make sense of the natural world by linking new experiences to them. Although publications like the Science for All Americans (AAAS, 1989) and NSES (NRC, 1996) stress learning with depth rather than covering many topics, the focus on covering many disciplinary content ideas continues to be practiced in schools (Kesidou \& Roseman, 2002; Roseman, 2010). Although documents like the Atlas of Science Literacy (AAAS, 2001) discuss and show connections among ideas, the major limitation of current conceptions of content knowledge is failure to see the relationships among ideas and the lack of unifying or core ideas across science disciplines that serve as organizing structures to build future ideas.

Key Elements of 21st Century Content Knowledge. Learners in the 21st century will need to grapple with issues related to climate change, consequences of genetic engineering, destruction of the environment, and lack of energy. Such problem solving will require learners to have an integrated understanding of the big ideas of science (Duschl et al., 2007; C. L. Smith et al., 2006; Stevens et al., 2009). Big ideas allow individuals to explain and predict a variety of phenomena they experience in their daily lives and form the foundation for future learning. By integrated understanding, we mean ideas connected to each other in such a manner that allow learners to be aware of and be able to use relationships among various ideas to predict phenomena as well as solve problems related to science and society (Bransford et al., 1999; Linn \& Eylon, 2006). Such conceptual understanding is key to solve problems (NRC, 2005). Moreover, big ideas also cut across traditional disciplinary boundaries (Millar, 2006; Tyler, 2007). This is a critical point because to solve challenging problems that occur in a global society often requires integration of ideas that cross-disciplinary boundaries.

We have identified several big ideas including: energy, particle nature of matter, biodiversity, patterns of change, systems and interactions, sustainability, scale and structure, and 
evolution and equilibrium. Our selection of big ideas is similar to the set of major scientific themes and their associated concepts put forth by OECD (2004) and the Conceptual Frameworks for New Science Education Standards (NRC, 2010). A focus on only a few powerful ideas is also consistent with Beyond 2000 (Millar \& Osborne, 1998), OECD (2004), and Millar (2006). We focus on big ideas because we see them as forming the foundation necessary to build conceptual frameworks that allow learners to connect new ideas and retrieve information (Bransford et al., 1999) for long term and continuous learning throughout an individual's life (Duschl et al., 2007; C. L. Smith et al., 2006; Wilson \& Berenthal, 2006). It is our hope that they can form the foundation for realizing that less is covered in the curriculum but that students learn more.

\section{Habits of Mind}

Habits of mind are important for individuals to develop, as they allow individuals to explore the world scientifically and resolve socio-scientific issues and problems. Scientific inquiry skills are often referred to as habits of mind. Inquiry skills have ranged from knowing how to use scientific tools to take measurements to know what counts as evidence to support a scientific claim (AAAS, 2007; NRC, 2000). However, our conception of habits of mind, while including these abilities and skills, go beyond them to include complex capabilities to solve problems and communicate with others. In the 21st century, science content knowledge is expanding rapidly and will continue to expand. Therefore, it is important to prepare citizens to become effective problem solvers by being able to communicate and collaborate with others. People need to be able to understand the goals of group activities, share cognitive and physical workloads, and assume appropriate roles and responsibilities. As such, habits of mind become essential components for joint intellectual efforts in the 21st century (Dewey, 1910; Steinkuehler \& Duncan, 2008).

Key Elements for the 21st Century Habit of Mind. Citizens of the 21st century will need to solve complex problems, collaborate, and communicate their ideas to others. As such, we emphasize the ability to solve personal, community and global problems collaboratively by critically examining issues, finding and using resources, applying big ideas, considering multiple perspectives, using evidence and arguing for and against positions. We define four key elements associated with developing habits of mind for the 21 st century: communication and collaboration skills, systematic thinking, the use of evidence to support claims, and build arguments and information management skills.

Communication involves individuals interpreting both verbal and nonverbal information from others in order to respond to the variety of demands in their daily lives and to build joint understandings (AAAS, 2007). A skilled communicator selects key pieces of a complex idea to express in words and images, in order to build shared understanding with others. Skilled communicators can also detect bias, overgeneralization, and unsupported claims in arguments. Collaboration includes knowing how to work, listen to, and communicate with a variety of individuals from diverse backgrounds to build shared understandings (Dillenbourg, 1999). Based on shared understanding, members use joint intellectual efforts and resources to investigate and resolve issues, problems, or questions and to actualize their understanding and meanings.

Systematic thinking allows individuals to see connections and relationships among components and use logical thinking about complex concepts and procedures to solve problems and understand events. As such, systematic thinking leads to creative problem solving as a result of flexible thinking and seeing connections. Blended with an integrated understanding 
of big ideas, individuals can think flexibly about a situation and take risks to create workable solutions to problems that do not have straightforward approaches or solutions.

The hallmark of science is the use of evidence to support claims and build arguments. This fundamental scientific practice of using evidence to support claims and arguments is not only essential for scientists, but for all citizens. Citizens in the 21 st century will need to know how to evaluate claims and arguments for appropriate and sufficient evidence. The use of evidence to support claims and arguments is part of the vision for scientific literacy by the OECD (2004), stressed in the US national science standards (AAAS, 1993; NRC, 1996), and recommended by the US National Research Council. The NRC in Taking Science to School (Duschl et al., 2007) synthesizes the latest educational research for K-8 science teaching and as a result advocates for students to generate and evaluate scientific evidence and explanations.

Information management provides learners with competencies necessary to find, manage, and evaluate information from one or more sources and to distribute that information to others in an intelligible manner. Information management involves recording and organizing large amounts of data, transforming data using tools, and reading and interpreting graphs. It also involves traditional inquiry skills of finding, evaluating, and synthesizing information. Moreover, learners need to know how to present this information using various techniques and representations that can be understandable to a variety of audiences.

\section{Character and Values}

Current views of science literacy focus on students developing positive attitudes or interest in science by creating contexts which students find motivating. The hope is that such environments will allow learners to take issues seriously and then act on them. We agree that interest and attitude are necessary, but they are not sufficient driving forces to engage students as 21 st century citizens.

Key Elements of Character and Value for the 21st Century. The 21 st century will require individuals to have the character and a value system that will enable them to act responsible with respect to human life and allow them to show compassion for other human beings throughout the globe. Individuals need to develop a value system and character that can serve as a general guide or point of reference to support decision-making about global socio-scientific issues (Berkowitz \& Simmons, 2003; Hodson, 2003; Zeidler \& Keefer, 2003; Zeidler, Sadler, Simmons, \& Howes, 2005). Once internalized, values and character will play a role in guiding actions, motivating attitudes toward relevant situations, and considering moral judgments about one's self and others (Rokeach, 1968).

Although individuals learn scientific knowledge related to socio-scientific issues, practice problem-solving skills, and develop understanding about different values in our society and the world, they experience challenges simultaneously using the components (knowledge, skills, etc.) with their own personal worldviews or values. For instance, Connell, Fien, Lee, Sykes, and Yencken (1999) reported that 16-17 years old students in Australia who faced environmental issues had overwhelming feelings of environmental concern but felt frustrated and helpless because there were too many aspects to be considered. H. Lee, Choi, and Chang (2006) found that college students considered their personal moral/ethical values, larger worldviews, and feelings when making decisions; however, the responses suggested that most did not take the socio-science issues seriously or merely quoted their own values without further engagement. Not just limited to college students, Cross and Price (1999) point out that many citizens view controversial scientific issues as outside their need and ability to 
judge. This work implies that science education needs to help individuals develop the character and values that that will lead to the development of integrity and personal identify that will allow individuals to take action as global citizens.

Blended with 21 st century integrated knowledge and habits of mind, values, and character provide the moral fabric individuals need to make decisions and take action for living in the 21 st century as global citizens who are compassionate and understand the cultures and ideas of other people. We specify three key elements associated with developing a value system for the 21 st century: ecological worldview, socio-scientific accountability, and social and moral compassion.

By ecological worldview we mean individuals develop the shared beliefs that all human lives are connected and that humans and the environment operate as an interconnected system with each component influencing the other. An ecological framework includes principles such as individuals developing a personal affinity with the earth through practical experience and ethics to care for the world (G. A. Smith \& Williams, 1999, pp. 6-7). People with an ecological worldview appreciate and make decisions based on the interdependence between humans and the environment. They understand that individual actions influence and have ramifications for the world in which they live. As such, they develop stewardship, and consider global welfare and goodness as a group (Carr, 2002). Zandvliet (2004) enhances the ecological framework and calls for an "eco-sphere consciousness" that allows students to reflect on who they are, what is important, and where they fit in nature. These reflections help individual's value and appreciate the enormity and beauty of nature, feel connected to it, and finally, take responsibility for the environment. Like Zandvliet, we want students to form values and develop themselves based on a conscious level of understanding.

Twenty-first century values also include socio-scientific accountability where individuals understand how science is related to society and recognize their responsibility as stakeholders on socio-scientific issues. Hodson (2003) emphasizes developing students' own values with respect to societal needs and taking sociopolitical action. Like Hodson (2003), we view one central goal of science education as providing students with the knowledge, habits of mind and commitment to take appropriate, responsible and effective action on social, economic, environmental and moral-ethical issues. Those who hold a worldview for the 21 st century can identify contemporary socio-scientific issues and seek to take action to participate in the decision-making process related to those issues to safeguard the world in which they live. Twenty-first century citizens (1) lead personally fulfilling and responsible lives, (2) become compassionate toward their fellow human beings and feel responsible to participate to protect human rights, and (3) understand the impact of personal action and their contribution to personal, societal, and global outcomes (Elmose \& Roth, 2005; Hodson, 2003; Roth, 2003; Roth \& Lee, 2004).

Those with 21st century values also demonstrate social and moral compassion. Compassion leads to understand the reasons for other peoples' actions, as it requires empathy (Ruiz \& Vallejos, 1999). Twenty-first century literacy will require the development of empathy for other human beings and the respect for other human beings and life throughout the world. Individuals with 21 st century values understand their own cultural background, and recognize that others can have different cultural backgrounds and appreciate cultural diversity.

\section{Science as Human Endeavor}

Science as human endeavor refers to individuals' understanding of the nature of science (NOS) in their personal, social, and global life. Individuals need to view science as a social 
activity that humans have practice throughout history (AAAS, 1989). Therefore, science reflects social values and viewpoints. Science education researchers have emphasized the importance of students' argumentation and discourse on various socio-scientific issues (Aikenhead, 2001; Driver, Leach, Millar, \& Scott, 1996; Driver, Newton, \& Osborne, 2000; Solomon, 1992; Zeidler, 1997; Zeidler, Lederman, \& Taylor, 1992) as an important aspect of NOS. In order to make decisions as informed citizens on socio-scientific issues (Aikenhead, 1985; Kolst $\varnothing, 2001$; Mead \& Scharmann, 1994; Zeidler, Walker, \& Ackett, 2002), students should also understand the social implications of science in the context of science-technology-society (STS).

In the 1960s, the emphasis was on inquiry and science process skills (e.g., observing, hypothesizing, inferring, interpreting data, and designing experiments). This perspective dominated science education into the 1990s. Science for All Americans (AAAS, 1989) describes three basic components underlying a sufficient understanding of the nature of science. The first component is a perspective that science cannot provide answers to all questions. The second is that scientific inquiry is based on imagination and the creation of explanations. The third emphasizes an understanding of the social and political aspects of science. NSES (NRC, 1996) have emphasized the historical, tentative, empirical, logical, and wellsubstantiated nature of science. They also have suggested that skepticism and open communication are critical elements of NOS.

Key Elements of Science as a Human Endeavor for the 21st Century. Twenty-first century scientific literacy requires a contemporary understanding of the NOS in order for individuals to appreciate the relationship among science, technology, and society based on science as a social activity. As such, understanding NOS helps students use scientific knowledge to make decisions, resolve issues, and vote intelligently with respect to what science can and cannot do. We also focus on science as a human activity. As citizens we need to make decisions about how science is used in our world. Individuals need to understand important features of science in order to deal with socio-scientific issues in a global context. Our focus on the understanding of socio-scientific issues from a global perspective distinguishes our ideas of science as a human endeavor from previous conceptions of NOS for scientific literacy. We specify three key elements associated with science as human endeavor for 21 st century scientific literacy: characteristics of scientific knowledge, science and society, and the spirit of science.

The essential characteristic of scientific knowledge results from human activity (Lederman, 1992) and is based upon theories which humans construct. As such, the knowledge scientists' produce is tentative, subjective, and theory-laden. At the same time the claims made by science are empirically testable. In addition, science has often developed through creative insights (Abd-El-Khalick, 2001) that have provided more thorough models and explanations of phenomena. However, science does not march towards "truth" as many falsely believe. Understanding the characteristics of scientific knowledge helps us to apply scientific knowledge when solving problems. Science as practiced is also becoming more interdisciplinary where groups of scientists come together to solve challenging problems that require the joint expertise of several individuals. This image of interdisciplinary science is in marked contrast to images of the lone scientist working in his lab to solve problems.

Science and technology are essential social enterprises and provide knowledge and products that society can use to solve problems, but how that knowledge and the products of science are used is a human decision. Science and technology only indicate what can happen, not what should happen (NRC, 1996). This is the critical aspect of science and society, as 
people make decisions about how the knowledge and products from science and technology are used.

Citizens should appreciate what science can reasonably contribute to society and what science cannot do. Therefore, we emphasize understanding the nature of scientific knowledge and its relation to society. We also see curiosity, creativity, intellectual honesty, tolerance of ambiguity, skepticism, and openness to new ideas as important factors for citizens to understand socio-scientific issues and respond to the challenges of decision-making in social and global contexts. We refer to this as the "spirit of science" in which individuals use science and tenets of the NOS to solve various socio-scientific problems.

\section{Metacognition and Self-Direction}

Metacognition and self-direction is the ability of an individual to actively use cognitive resources to regulate his or her own thinking and the use of cognitive processes, such as planning, monitoring, and evaluating, in order to improve understanding on their own initiatives (Collins, 1994; Leahey \& Harris, 1997; Maitland, 2000). It is essential for adaptive learning and lifelong learning for self-motivated pursuit of knowledge for enhancing social inclusion, active citizenship, and personal development throughout life (Commission of the European Communities, 2006; Department of Education and Science, 2000). As we move further into the 21 st century and the world will become an even more information and knowledge driven society, the capacity to direct and regulate one's own learning is crucial. Although this dimension is certainly a key idea when it comes to learning (Beeth, 1998; Blank, 2000; Bransford et al., 1999; Georghiades, 2004; Thomas, 2003), it is not discussed in the literature on scientific literacy nor is it a focus of curriculum documents and learning materials with the exception of few reformed-based curricula. In our conceptual framework as shown in Figure 1, we locate metacognition and self-direction in the middle as it serves as an integrating component, allowing a learner to reflect on the other dimensions. In other words, metacognition serves an integrating role in governing the regulation of the other four dimensions, as it is the essential capability that informs an individual if she thoroughly comprehends or is prepared along a particular dimension.

Key Elements of Metacognition and Self-Direction for 21st Century Scientific Literacy. For making decisions or choices on critical social issues or for solving complex everyday problems, twenty-first century citizens will face large quantities of new information for which they will need to plan, monitor, or evaluate when they need more information, what information they need, and whether they understand the information they find (Sutherland, Shin, \& Krajcik, 2010). Learning should take place on a daily basis through on-going interactions with others and with the world around us to effectively use and take advantage of scientific and technological innovation and change in the 21st century (Fischer, 2000). Thus, 21st century scientific literacy will require the use of skills such as changing strategies, modifying plans, and reevaluating goals in order to organize and direct cognitive endeavors in different ways and to a different degree. Therefore, we identify three key elements associated with the regulation aspect of metacognition for 21 st century scientific literacy: self-directed planning, self-directed monitoring, and self-directed evaluating (Brown, 1987; Leahey \& Harris, 1997). Researchers have emphasized that the regulation aspect of metacognition plays an important role in obtaining meaningful understanding of science, and in deciding which strategies are most appropriate for complex and nonroutine problem solving and decision-making (Shin, Jonassen, \& McGee, 2003). 
Self-directed planning helps an individual decide what needs to be done to accomplish a particular task (e.g., solving problems or issues, making decisions) (Voss, Lawrence, \& Engle, 1991). It involves the selection of appropriate strategies and allocation of resources that effect performance (Schraw \& Moshman, 1995). It is the cognitive activity that allows us to trade-off more complete and elaborate plans with the need for flexibility of action to decide what steps need to be taken to finish a task in an efficient manner (Brown, Bransford, Ferrara, $\&$ Campione, 1983). These emergent constructions arise from feedback from monitoring process, as well as from reflections on the outcome of previous actions. The monitoring process supports an individual in tracking his/her working process, and in noting his/her limitations, and the effects of his/her efforts (Kluwe \& Friedrichsen, 1985). Self-directed monitoring refers to one's awareness of comprehension and task performance while in the process of performing a specific task (Nietfeld, Cao, \& Osborne, 2005). It helps to examine the flow of activities and evaluate each activity to make sure that the plan is working and being accomplished. Self-directed evaluating refers to appraise the products and regulatory process of one's learning (Schraw \& Moshman, 1995). It allows the individual to look back on his/her working process and decide if an appropriate resolution has been met (Sinnott, 1989). Those with good evaluation skills can correct and modify strategies when obstacles are encountered and when initial plans fail. Self-directed evaluating also helps an individual to reflect upon past work and to adapt past experiences to similar learning activities in the future.

In the 21 st century, metacognition and self-direction will play an even greater role for global citizens as they encounter various problems that relate to personal, social and global issues because of the enormous amount of knowledge and diverse cultures and values that exist. With respect to content knowledge, metacognition and self-direction allows an individual to decide if he grasps a particular idea and how it relates to other ideas. Knowing if one understands an idea is a critical aspect when attempting to solve a problem. With respect to habits of mind, metacognition and self-direction allows an individual to judge if she has sufficient and appropriate evidence to support an argument. It also helps an individual judge if her communication is clear or if she needs to re-explain the idea to others. When seeking new information, an individual's metacognition is critical to determine if the individual understands the new information. With respect to character and value, metacognition and self-direction supports an individual in seeing how the perspectives of others are similar or different from one's own. It helps an individual in considering whether we are pursuing global welfare on the basis of ecological consciousness and social/moral compassion. In addition, metacognition and self-direction is the element that allows an individual to know if they are aware of an issue, and if they are or are not acting responsibly or taking action. It is also critical for comprehending and applying the nature of science for it allows an individual to evaluate the limitations and affordances that different models might hold. Finally, it allows an individual to be skeptical of new claims and pushes an individual to seek other possible ways of solving various problems. Because metacognition works with each of the other components to promote understanding of these ideas, we see it as the component that connects the each of the other elements.

\section{Conclusion}

As we move from a context that focuses on the individual and society to a more global context, the science education community needs to rethink what all students need to understand to live in the 21 st century. We have redefined and expanded the view of scientific literacy for South Korea by articulating and identifying new aspects of the four traditional dimensions of scientific literacy as well as adding a vital fifth dimension, metacognition and 
self-direction. However, this framework also promises to be important for other nations throughout the globe, as the framework represents a substantial and important addition to the conception of scientific literacy. As with other frameworks, we include individual and society perspectives. However, we move beyond these two perspectives and add a global perspective as an additional and essential 21st century perspective that all citizens must hold in order to be global citizens. Although the ideas in the framework align with those in OECD (2004); Beyond 2000 (Millar \& Osborne, 1998) and the New Conceptual Frameworks (NRC, 2010) with respect to students understanding big ideas of science and the importance of evidence and communications, the framework also calls for scientific literacy to include character and values, and metacognition.

As such, the framework represents a new perspective for scientific literacy for South Korea and, potentially for every nation. First, we emphasize the importance of learning a few core ideas over time in the context of meaningful environments (Duschl et al., 2007; C. L. Smith et al., 2006) in order for learners to build integrated conceptual understandings that can be added to and developed throughout life. This is consistent with the direction that science educators in South Korea are currently pursuing, but as of yet are not being practiced in schools. As such, this is a major shift in the approach to learn that currently occurs in South Korean schools and as such presents a new vision for curriculum reform and development. We are concerned that our students are overwhelmed by too many scientific concepts and vocabularies terms and will lose interest in science (Kim, 2001). As shown in the contrast between PISA and TIMSS results, Korean students need to learn how to approach scientific problems on the basis of integrated and context-based understanding of core science ideas.

Second, although science educators have historically stressed the importance of higher order thinking and science processes (AAAS, 1993) and more recently the use of evidence to support claims (Millar \& Osborne, 1998; NRC, 2010), our framework stresses the importance of communication and collaboration, systematic thinking including nonroutine problem solving, the use of evidence to support claims, and information management within the habits of mind dimension. These aspects of habits of mind are essential capabilities for successful citizenship in the 21 st century, yet these ideas are not a focus of curriculum frameworks. The survey results of Korean and US science teachers also supported this. Teachers do not much pay attention to enhance information management and communication and collaboration skills. Students need to learn how to put ideas together and work with others to come up with novel solutions to challenging problems.

Third, the new framework goes beyond attitudes and motivation to focus on the development of character and values as global citizens (Berkowitz \& Simmons, 2003; Hodson, 2003; Zeidler et al., 2005). This focus is a significant departure from previous views of science literacy. In order to cope with the global socioscientific issues that occur in the different places in the world and affect other parts of the world, we need to nurture individuals who are able to appreciate diversity of values and cultures surrounding issues, to have compassion for others, collaboratively construct values for the larger welfare, and ultimately take action. South Koreans are threatened by nuclear weapons from North Korea, but this is not an issue only for South Koreans, but one for welfare of individuals throughout the globe. Similarly, devastating earthquakes have caused people in Japan and Chile to greatly suffer, but this cannot be seen as only a local issue. Students can no longer remain passive about global issues that impact the planet. The focus on values and character is a major shift in the approach to learning that needs to occur in South Korean schools and in schools throughout the globe. National Science Curriculum in South Korea only mentions "interest in science," but the framework suggests that having interest in science and scientific issues is not enough. 
Beyond implementing STS materials (Zeidler et al., 2005), we need to consider developing appropriate character and values so that individuals will take action.

Forth, understanding science as a human endeavor has been an important aspect of science education (Abd-El-Khalick, 2001; Lederman, 1992) and stressed in most documents related to scientific literacy (Millar \& Osborne, 1998; NRC, 1996; OECD, 2004). For instance, science content standards in NSES (NRC, 1996) include two categories of science and technology, science in personal and social perspectives, and history and nature of science. And more than 30 state level curriculum documents in the US mentions these aspects $(\mathrm{H}$. Lee $\&$ Chang, 2007). However, little work has been done in South Korean curriculum and classroom instructions to help teachers and students understand that science is a human activity, particularly with respect to understand science as a collaborative and interdisciplinary effort, the tentativeness of science knowledge and how knowledge is theory laden. National Science Curriculum in South Korea only includes "understanding the interrelationship among science, technology and society" as a subgoal (MEHRD, 2007). Recent work by Millar (2006) and Schwarz et al. (2009) stress students engaging in more scientific practices like modeling and the use of evidence and argumentation. Such work in classrooms that occurs over time holds promise in helping learners develop more appropriate understandings of science as a human activity.

The final dimension we consider in our picture of scientific literacy for the 21 st century is metacognition and self-direction. Although metacognition has been stressed in the literature (Bransford et al., 1999) it is not a focus in the scientific literacy literature. And with the exception of some research for developing new reform-based curriculum (see for instance, Linn \& Eylon, 2006), very little is actually done in curriculum materials to promote this important aspect of learning. Because knowledge will continue to develop, all citizens will need to seek new information to solve problems and make decisions. Metacognition and selfdirection helps plan and guide the learning of new information. This focus on metacognition and self-direction also represents a significant departure from previous views of science literacy and how instruction is done in most classrooms in South Korea and other nations.

As discussed earlier, we do not see these five elements as separate, but rather as five elements that work together in an integrated fashion to form understanding. This focus of the five elements developing together is a new focus for scientific literacy and for K-12 science instruction. Our hypothesis is that if school systems in South Korea and worldwide work together to design curriculum that help individuals develop these five elements in an integrated and blended way, individuals will develop very different capabilities and understandings then students who graduate from current school systems. We will have a populace of learners who know (1) how to seek information when needed, (2) when they do not understand, (3) how to consider the views of others, (4) if they have enough information and evidence to support their position and (5) if when other possible explanations are ruled out or tenable. Moreover, what is critical and what does not happen in school systems throughout the world is the focus of these five dimensions throughout the K-12 science learning experience. The acceptance of this framework calls for long-term development of curriculum and assessment. As such, this framework calls for major changes in South Korean schools and for other nations who adopt this framework.

We hope this framework will serve as a call to the global science education community to work together to improve the teaching and learning of science throughout the world. Noble Laureate Leon Lederman, in his remarks at the World Conference On Science-Science For The Twenty-First Century: A New Commitment (UNESCO, 2000) stated "Universal science education is a key to any hopes for 'a new commitment of science for human welfare", 
(p. 163). The framework could serve as a unifying vehicle for countries to work together to improve the teaching and learning of science by sharing standards, curriculum, assessments, and professional development plans. As such, it can be a guide to design and development of new standards, curriculum materials, instructional techniques, and assessments not only for South Korea, but also for other nations. As such, the framework can also serve to guide future research on how students develop throughout the K-12 science learning experience. We conjecture that students who experience curriculum and instruction that focuses on the five dimensions throughout their schooling will be very different individuals than those who now graduate from our schools.

As we move forward we need to work together to clarify and refine each dimension of the framework and to answer the following questions: What key ideas in science should be our focus? How can we support students in building character and values that guide them in decision-making? How can we help students develop important metacognitive capabilities? How can we carefully craft curriculum that builds over time? How should teachers be prepared to teach such a curriculum? How can we make use of breakthroughs in information and computing technologies to support student learning about these new ideas? These are difficult and challenging questions that we need to act on immediately; otherwise, we will fail to help our students develop knowledge and capabilities they will need as 21 st century citizens. These questions represent only a small subset of questions that stem from the new framework. Answers to challenging questions will need to be guided by research and what is known about student learning. To answer these challenging questions and obtain the needed research will require the collective effort of a diverse and international perspective.

This research was supported by WCU (World Class University) program through the National Research Foundation of Korea funded by the Ministry of Education, Science and Technology (R32-20109). The authors thank the Research Group of the Global Institute for Science, Technology \& Society Education at Ewha Womans University, South Korea. In particular, we wish to acknowledge the data collection and analysis efforts of Kongju Mun, SohyunYoon, and Kayoun Chung. We would also like to thank Professor David Treagust from Curtin University in Australia, Professor Brian Coppola the University of Michigan in the USA, and Ann Novak from Greenhills School in Ann Arbor, MI, USA for their helpful commentary on previous drafts of the manuscript.

\section{References}

Abd-El-Khalick, F. (2001). Embedding nature of science instruction in preservice elementary science courses: Abandoning scientism. Journal of Science Teacher Education, 12(3), 215-233.

Aikenhead, G. S. (1985). Collective decision making in the social context of science. Science Education, 69(4), 453-475.

Aikenhead, G. S. (2001). Renegotiating the culture of school science. In R. Millar, J. Leach, \& J. Osborne (Eds.), Improving science education: The contribution of research (pp. 245-264). Buckingham: Open University Press.

American Association for the Advancement of Science [AAAS]. (1989). Project 2061—Science for all Americans. Washington, DC: AAAS.

American Association for the Advancement of Science [AAAS]. (1993). Benchmarks for science literacy. New York: Oxford University Press.

American Association for the Advancement of Science [AAAS]. (2001). Atlas of science literacy. Washington, DC: AAAS.

American Association for the Advancement of Science [AAAS]. (2007). Atlas of science literacy. Washington, DC: AAAS. 
Arons, A. B. (1983). Achieving wider scientific literacy. Daedalus, 112(2), 91-122.

Beeth, M. E. (1998). Teaching for conceptual changes: Using status as a metacognitive tool. Science Education, 82(3), 343-356.

Berkowitz, M. W., \& Simmons, P. (2003). Integrating science education and character education. In D. L. Zeidler (Ed.), The role of moral reasoning on socioscientific issues and discourse in science education (pp. 117-138). Dordrecht, the Netherlands: Kluwer Academic Publishers.

Blank, L. M. (2000). A metacognitive learning cycle: A better warranty for student understanding? Science Education, 84(4), 486-506.

Bowen, G. M., \& Roth, W. M. (2007). The practice of field ecology: Insights for science education. Science Education, 37(2), 171-187.

Bransford, J., Brown, A. L., \& Cocking, R. (1999). How people learn: Brain, mind, experience and school. Washington, DC: National Academy Press.

Brown, A. L. (1987). Metacognition, executive control, self-regulation, and other more mysterious mechanisms. In F. Weinert, \& R. Kluwe (Eds.), Metacognition, motivation, and understanding (pp. 65116). Hillsdale, NJ: Erlbaum.

Brown, A. L., Bransford, J., Ferrara, R., \& Campione, J. (1983). Learning, remembering, and understanding. In P. H. Mussen (Ed.), Handbook of child psychology: Vol. III (pp. 77-166). New York: Wiley.

Bybee, R. W. (1997). Towards an understanding of scientific literacy. In W. Graber \& C. Bolte (Eds.), Scientific literacy (pp. 37-68). Kiel, Germany: Institute for Science Education (IPN).

Carr, A. (2002). Grass roots and green tape: Principles and practices of environmental stewardship. Sydney: Federation Press.

Chen, F., Shi, Y., \& Xu, F. (2009). An analysis of the public scientific literacy study in china. Public Understanding of Science, 18(5), 607-616.

Collins, N. (1994). Metacognition and reading to learn (on-line). Available at: http://www.ed.gov/ databases/ERIC_Digests/ed376427.html.

Commission of the European Communities. (2006). Adult learning: It is never too late to learn. COM (2006) 614 final. Brussels. Available at: http://eur-lex.europa.eu/LexUriServ/site/en/com/2006/ com2006_0614en01.pdf.

Conant, J. B. (1951). Science and common sense. New Haven: Yale University Press.

Connell, S., Fien, J., Lee, J., Sykes, H., \& Yencken, D. (1999). 'If it doesn't directly affect you, you don't think about it': A qualitative study of young people's environmental attitudes in two Australian cities. Environmental Education Research, 5(1), 96-113.

Cross, R. T., \& Price, R. F. (1999). The social responsibility of science and the public understanding of science. International Journal of Science Education, 21(7), 775-785.

DeBoer, G. E. (2000). Scientific literacy: Another look at its historical and contemporary meanings and its relationship to science education reform. Journal of Research in Science Teaching, 37(6), 582601.

Department of Education and Science. (2000). Learning for life: White paper on adult education. Dublin: Stationery Office. Available at: http://eric.ed.gov/ERICDocs/data/ericdocs2sq1/content_storage_01/0000019b/80/1a/c6/5e.pdf.

Dewey, J. (1910). Science as subject matter and as method. Science \& Education, 4(4), 391-398.

Dillenbourg, P. (1999). What do you mean by collaborative learning? In P. Dillenbourg (Ed.), Collaborative-learning: Cognitive and computational approaches (pp. 1-19). Oxford: Elsevier.

Driver, R., Leach, J., Millar, R., \& Scott, P. (1996). Young people's images of science. Bristol, PA: Open University Press.

Driver, R., Newton, P., \& Osborne, J. (2000). Establishing the norms of scientific argumentation in classrooms. Science Education, 84(3), 287-312.

Duschl, R. A., Schweingruber, H. A., \& Shouse, A. (2007). Taking science to school: Learning and teaching science in grades K-8. Washington, DC: National Academies Press.

Elmose, S., \& Roth, W. M. (2005). Allgemeinbildung: Readiness for living in risk society. Journal of Curriculum Studies, 37(1), 11-34. 
Fischer, G. (2000). Lifelong learning-More than training. Journal of Interactive Learning Research, 11(3/4), 265-294.

Friedman, T. (2007). The world is flat: A brief history of the twenty-first century. New York: Farrar, Straus and Giroux.

Georghiades, P. (2004). Making pupils' conceptions of electricity more durable by means of situated metacognition. International Journal of Science Education, 26(1), 85-99.

Gilbert, J. (2003). Science education: Global or national. In J. Gilbert (Ed.), The RoutledgeFalmer reader in science education (pp. 1-12). London and New York: RoutledgeFalmer, Taylor and Francis Group.

Gore, A. (2006). An inconvenient truth. New York: Rodale.

Heisenberg, W. (1958). The physicist's conception of nature. New York: Harcourt, Brace \& Co.

Hodson, D. (2003). Time for action: Science education for an alternative future. International Journal of Science Education, 25(6), 645-670.

Holbrook, J., \& Rannikmae, M. (2007). The nature of science education for enhancing scientific literacy. International Journal of Science Education, 11(3), 1347-1362.

Hurd, P. D. (1998). Scientific literacy: New minds for a changing world. Science Education, 82(3), 407-416.

Jenkins, E. W. (1999). School science, citizenship and the public understanding of science. International Journal of Science Education, 21(7), 703-710.

Kang, I., Park, H., \& Baek, K. (2008). Toward a curricular balance of high school in global age. The Journal of Curriculum Studies, 26(3), 69-96.

Kesidou, S., \& Roseman, J. E. (2002). How well do middle school science programs measure up? Findings from Project 2061's curriculum review. Journal of Research in Science Teaching, 39(6), 522549.

Kim, J. (2001). The characteristics of the 7th national science curriculum of the Republic of Korea. Journal of the Korean Association for Research in Science Education, 21(5), 1012-1026.

Kluwe, R. H., \& Friedrichsen, G. (1985). Mechanisms of control and regulation and problem solving. In J. Kuhl, \& J. Beckman (Eds.), Action control (pp. 203-217). Berlin: Springer-Verlag.

Kolst $\varnothing$, S. D. (2001). Scientific literacy for citizenship: Tools for dealing with the science dimension of controversial socio-scientific issues. Science Education, 85(3), 291-310. 94.

Laugksch, R. C. (2000). Scientific literacy: A conceptual overview. Science Education, 84(1), 71-

Leahey, T., \& Harris, R. (1997). Learning and cognition. New Jersey: Prentice Hall.

Lederman, N. G. (1992). Students' and teachers' conceptions of the nature of science: A review of the research. Journal of Research in Science Teaching, 29(4), 331-359.

Lee, H., \& Chang, H. (2007). The comparison of state-level U.S. science curricula with science teachers' perception regarding teaching socioscientiifc issues (SSI). The Journal of Curriculum and Evaluation, 10(1), 189-209.

Lee, H., Choi, K., \& Chang, H. (2006). Patterns of college students' moral engagement with socioscientific issues. Journal of the Korean Association for Research in Science Education, 26(5), 646-659.

Lee, M., Sohn, W., \& No, U. (2008). The result from PISA 2006(RRE 2008-10). Korea Institute for Curriculum and Evaluation.

Linn, M. C., \& Eylon, B. (2006). Science education: Integrating views of learning and instruction. P. A. Alexander, \& P. H. Winne (Eds.), Handbook of educational psychology. (2nd ed.). Mahwah, NY: Lawrence Erlbaum Associates.

Maitland, L. (2000). Ideas in practice: Self-regulation and metacognition in the reading lab. Journal of Developmental Education, 24(2), 26-32.

Martin, M. O., Mullis, I. V. S., \& Foy, P., (2008) TIMSS 2007 international science report. TIMSS \& PIRLS International Study Center.

Mead, J. M., \& Scharmann, L. C. (1994). Enhancing critical thinking through structured academic controversy. American Biology Teacher, 56(7), 416-419. 
Millar, R. (2006). Twenty first century science: Insights from the design and implementation of a scientific literacy approach in school science. International Journal of Science Education, 28(13), 14991521 .

Millar, R., \& Osborne, J. (1998). Beyond 2000: Science education for the future. King's College London: Fulmar Colour Printing Company Limited.

Miller, J. D. (1998). The measurement of civic scientific literacy. Public Understanding of Science, 7, 203-223.

Ministry of Education. (1992). The 6th Korea national curriculum standards. Seoul: Daehan Printing and Publishing Co.

Ministry of Education. (1997). The 7th Korea national curriculum standards. Seoul: Daehan Printing and Publishing Co.

Ministry of Education and Human Resources Development [MEHRD]. (2007). The revised 7th Korea national curriculum standards in 2007. Seoul: MEHRD.

Ministry of Education Science Technology [MEST]. (2009). The revised 7th Korea national curriculum standards in 2009. Seoul: MEST.

National Research Council [NRC]. (1996). National science education standards. Washington, DC: National Academy Press.

National Research Council [NRC]. (2000). Inquiry and the national science education standards: A guide for teaching and learning. Washington, DC: National Academy Press.

National Research Council [NRC]. (2005). How students learn: Science in the classroom. M. S. Donovan, \& J. D. Bransford (Eds.), Committee on how people learn, a targeted report for teachers. Washington, DC: The National Academies Press.

National Research Council [NRC]. (2010). Conceptual framework for new science education standards. Available at: http://www7.nationalacademies.org/bose/Standards_Framework_Homepage.html.

National Science Board. (1996). Science and engineering indicators 1996. Washington, DC: US Government Printing Office.

National Science Board. (1998). Science and engineering indicators 1998. Washington, DC: US Government Printing Office.

Nietfeld, J. L., Cao, L., \& Osborne, J. W. (2005). Metacognitive monitoring accuracy and student performance in the postsecondary classroom. The Journal of Experimental Education, 74(1), 7-28.

Norris, S. P., \& Phillips, L. M. (2003). How literacy in its fundamental sense is central to scientific literacy. Science Education, 87(2), 224-240.

Oppenheimer, J. R. (1954). Science and the common understanding. New York: Simon and Schuster.

Organization for Economic and Co-operation and Development [OECD]. (2004). Scientific literacy. In J. Gilbert (Ed.), The RoutledgeFalmer reader in science education (pp. 39-52). London and New York: RoutledgeFalmer, Taylor and Francis Group.

Organization for Economic and Co-operation and Development [OECD]. (2005). The definition and selection of key competencies: Executive summary. Available at: http://www.oecd.org/dataoecd/47/ 61/35070367.pdf.

Organization for Economic Cooperation and Development [OECD]. (2007). PISA 2006 science competencies for tomorrow's world. Paris, France: OECD.

Partnership for the 21st Century Skills [P21]. (2009). 21st century skills science map. Tucson, AZ: P21.

Pella, M. O., O'Hearn, G. T., \& Gale, C. G. (1966). Referents to scientific literacy. Journal of Research in Science Teaching, 4, 199-208.

Rokeach, M. (1968). Beliefs, attitudes, and values. (1st ed.). San Francisco: Jossey-Bass.

Roseman, J. E. (2010). Linking textbooks to science. Issue of Better: Evidenced Based Education Learning, 2(3), 8-11.

Roth, W. M. (2003). Scientific literacy as an emergent feature of collective human praxis. Journal of Curriculum Studies, 35(1), 9-23. 
Roth, W. M., \& Lee, S. (2004). Science education as/for participation in the community. Science Education, 88(2), 263-294.

Ruiz, P. O., \& Vallejos, R. M. (1999). The role of compassion in moral education. Journal of Moral Education, 28(1), 5-17.

Schraw, G., \& Moshman, D. (1995). Metacognitive theories. Educational Psychological Review, 7(4), 351-371.

Schwarz, C., Reiser, B., Davis, E., Kenyon, L., Acher, A., Fortus, D., ... Krajcik, J. S. (2009). Developing a learning progression for scientific modeling: Making scientific modeling accessible and meaningful for learners. Journal of Research in Science Teaching, 46(1), 232-254.

Shamos, M. H. (1995). The myth of scientific literacy. New Brunswick, NJ: Rutgers University Press.

Shen, B. S. P. (1975). Science literacy and the public understanding of science. In S. B. Day (Ed.), Communication of scientific information (pp. 44-52). Basel, Switzerland: S. Karger AG.

Shin, N., Jonassen, H. D., \& McGee, S. (2003). Predictors of well-structured and ill-structured problem solving in an astronomy simulation. Journal of Research in Science Teaching, 40(1), 7-27.

Shin, N., Stevens, S. Y., \& Krajcik, J. (2011). Using construct-centered design as a systematic approach for tracking student learning over time. London: Taylor \& Francis Group.

Sinnott, J. D. (1989). Everyday problem solving: Theory and applications. New York: Praeger.

Smith, C. L., Wiser, M., Anderson, C. W., \& Krajcik, J. (2006). Implications of research on children's learning for standards and assessment: A proposed learning progression for matter and the atomic molecular. Theory Measurement: Interdisciplinary Research and Perspectives, 14(1\&2), 1-98.

Smith, G. A., \& Williams, D. R. (1999). Ecological education in action: On weaving education, culture, and the environment. Albany, NY: State University of New York Press.

Solomon, J. (1992). The classroom discussion of science-based social issues presented on television: Knowledge, attitudes, and values. International Journal of Science Education, 14(4), 431-444.

Steinkuehler, C., \& Duncan, S. (2008). Scientific habits of mind in virtual worlds. Journal of Science Education and Technology, 17(6), 530-543.

Stevens, S., Sutherland, L., \& Krajcik, J. S. (2009). The big ideas of nanoscale science and engineering. Arlington, VA: National Science Teachers Association Press.

Sutherland, L. M., Shin, N., \& Krajcik, J. S. (2010). Exploring the relationship between 21st century competencies and core science content. Paper commissioned by the National Academies. Washington, DC: National Research Council.

Thomas, G. P. (2003). Conceptualisation, development and validation of an instrument for investigating the metacognitive orientation of science classroom learning environments: The metacognitive orientation learning environment scale-science (MOLES-S). Learning Environments Research, 6(2), 175-197.

Tyler, R. (2007). Re-imagining science education: Engaging students in science for Australia's future. Australia: ACER Press, Australian Council for Educational Research, Camberwell, Victoria.

UNESCO. (2000). Science for the twenty-first century: A new commitment. Available at: http:// www.unesco.org/science/wcs/index.htm.

Voss, J. F., Lawrence, J. A., \& Engle, R. A. (1991). From representation to decision: An analysis of problem solving in international relations. In R. J. Sternberg, \& P. A. Frensh (Eds.), Complex problem solving (pp. 119-157). Hilldale, NJ: Lawrence Erlbaum.

Wilson, M. R., \& Berenthal, M. W. (2006). Systems for state science assessment. Washington, DC: National Academies Press.

Zandvliet, D. (2004). Developing an ecological framework for environmental education. Paper presented at the Annual Meeting of the National Association for Research in Science Teaching, Vancouver BC, Canada

Zeidler, D. L. (1997). The central role of fallacious thinking in science education. Science Educator, 7(1), 38-46.

Zeidler, D. L., \& Keefer, M. (2003). The role of moral reasoning and the status of socio-scientific issues in science education. In D. L. Zeidler (Ed.), The role of moral reasoning on socio-scientific issues 
and discourse in science education (pp. 7-38). Dordrecht, the Netherlands: Kluwer Academic Publishers.

Zeidler, D. L., Lederman, N. G., \& Taylor, S. C. (1992). Fallacies and student discourse: Conceptualizing the role of critical thinking in science education. Science Education, 76(4), 437-450.

Zeidler, D. L., Sadler, T. D., Simmons, M. L., \& Howes, E. V. (2005). Beyond STS: A researchbased framework for socio-scientific issues education. Science Education, 89(3), 357-377.

Zeidler, D. L., Walker, K. A., \& Ackett, W. A. (2002). Tangled up in views: Beliefs in the nature of science and responses to socio-scientific dilemmas. Science Education, 86(3), 343-367. 